\title{
EFFECT OF THE SOCIAL MEDIA MARKETING STRATEGY ON CUSTOMER PARTICIPATION INTENTION IN LIGHT OF THE MEDIATING ROLE OF CUSTOMER PERCEIVED VALUE
}

\section{UTJECAJ MARKETINŠKE STRATEGIJE DRUŠTVENIH MEDIJA NA KORISNIKOVU NAMJERU SUDJELOVANJA U ODNOSU NA MEDIJATORSKU ULOGU KORISNIKOVE PERCIPIRANE VRIJEDNOSTI}

\author{
Market-Tržište \\ Vol. 33, No. 1, 2021, pp. 41-58 \\ UDK 004.738.5:658.8:368(55) \\ DOI http://dx.doi.org/10.22598/mt/2021.33.1.41 \\ Preliminary communication
}

\section{Ardeshir Bazrkara, Mohammad Hajimohammadib, Erfan Aramoonc, Vahid Aramoon ${ }^{\text {d }}$}

a Islamic Azad University, Department of Industrial Management, North Tehran Branch, Tehran, IRAN, e-mail: Ardeshir.Bazrkar@gmail.com

b Islamic Azad University, Department of Public Management, North Tehran Branch, Tehran, IRAN, e-mail: Mohammad.Hmohammadi64@gmail.com

' Islamic Azad University, Department of Industrial Engineering, Tehran, IRAN, e-mail: Erf.Aramoon@gmail.com

d Islamic Azad University, Department of Industrial Management, Tehran, IRAN, e-mail: Vahid.Aramoon@gmail.com

\begin{abstract}
Purpose - The main purpose of this study is to assess the effect of social media marketing strategy components on customer participation with organizations active in the Iranian insurance industry, taking into account the mediating role of value perceived by insurance service customers.
\end{abstract}

Design/Methodology/Approach - This is an applied research study based on the objective and a descriptive survey. A questionnaire was used in the research to collect the research data among the customers of Iranian insurance companies. Fifteen insurance compa-

\section{Sažetak}

Svrha - Glavna svrha studije jest procijeniti učinak komponenata marketinške strategije društvenih medija na sudjelovanje korisnika u uslugama u iranskoj industriji osiguranja, a s obzirom na medijatorsku ulogu percipirane vrijednosti korisnika usluge osiguranja.

Metodološki pristup - Radi se o primijenjenom, opisnom anketnom istraživanju. Za prikupljanje podataka korišten je anketni upitnik. Statistički skup istraživanja činila su aktivna poduzeća u iranskoj industriji osiguranja. Metodom slučajnog uzorkovanja odabran je uzorak od 15 osiguravajućih poduzeća. Ispitanici koji su sudje- 
nies were randomly selected for the sample using the simple random sampling method. The respondents to the questionnaires were identified using a judgmental method.

Findings and implications - The results of this study show that social media marketing strategy has a positive and significant effect on customer participation intention. The results also indicated that the perceived value of customers in the insurance industry plays a mediating role in the relationship between the social media marketing strategy and customer participation intention. Companies working in the insurance industry as well as other service-providing organizations can apply the findings of this research to enhance the level of participation of their customers and improve the performance of social media marketing in attracting customers.

Limitations - Since this is an exploratory study, the research findings are limited to the specific sample, and thus, the results may change in the case of changes in the sample size. Also, different opinions about the research topic among members of the sample population can affect the research results to a certain extent.

Originality - Proper analysis of the impact of social media marketing strategies on customer participation intention, and attention to the perceived value of customers when receiving insurance services, is crucial in improving the performance of insurance companies. This is the first time that research on the Iranian insurance industry was conducted for this purpose and the results can be very effective.

Keywords - social media marketing strategy, customer participation intention, customer perceived value, Iran insurance industry lovali u anketnom istraživanju odabrani su na temelju prosudbe.

Rezultati i implikacije - Rezultati studije otkrili su da marketinška strategija društvenih medija ima pozitivan i značajan učinak na namjeru sudjelovanja korisnika. Rezultati su također pokazali da percipirana vrijednost korisnika u industriji osiguranja igra posredničku ulogu u odnosu između marketinške strategije društvenih medija i namjere sudjelovanja korisnika. Poduzeća u industriji osiguranja, kao i druge uslužne organizacije, mogu koristiti zaključke ovog istraživanja kako bi unaprijedili razinu sudjelovanja korisnika usluga i poboljšali učinkovitost marketinga na društvenim medijima radi privlačenja korisnika usluga.

Ograničenja - S obzirom da se radi o izviđajnom istraživanju, rezultati su ograničeni veličinom uzorka pa se mogu i promijeniti ako se promijeni veličina uzorka. Osim toga, različita mišljenja o temi istraživanja među ispitanicima mogu donekle utjecati na rezultate.

Doprinos - Pravilna analiza utjecaja marketinških strategija društvenih medija na korisnikovu namjeru sudjelovanja, kao i njegovu pozornost na percipiranu vrijednost pri korištenju usluga osiguranja, presudni su za poboljšanje poslovanja osiguravajućih poduzeća. Ovo je prvi put da se u iranskoj osiguravajućoj industriji provodi istraživanje u tu svrhu, a dobiveni rezultati mogu biti korisni.

Ključne riječi - marketinška strategija društvenih medija, korisnikova namjera sudjelovanja, korisnikova percipirana vrijednost, iranska industrija osiguranja 


\section{INTRODUCTION}

There are methods to maintain customer loyalty in order to stay and survive in the competitive marketplace (Ningsih \& Segoro, 2014). One of these methods is to optimally and continuously use social media and networks so that their high popularity and potential advantages, such as easy and extensive access, perceptual cost, and diverse performance in communications, encourage many companies to participate in such an environment (Ferreira, da Rocha \& Ferreira da Silva, 2014). Social networks and media have provided fertile ground for access to a new form of communicating and sharing content on the Internet, which quickly develops the elements of success crucial to changing the mindset of the company and adopting new strategies in response to the preferences of consumers by strengthening and creating a brand (Kohli, Suri \& Kapoor, 2015). A wide diversity of social media tools enables companies to communicate with a wide range of their potential and current customers (Chang, Yu \& Lu, 2015). Companies need to communicate with customers to properly send their products to them, benefit from their ideas, learn from them, and meet their social needs (Ferreira et al., 2014). Creating value for the customer and improving the quality of the customer relationship are the two main elements for developing customer loyalty. The more valuable the customers perceive the services provided, the higher the probability that the company's customer relationship is established at the desired level and in turn customer loyalty also develops in proportion and customers become more loyal to the company. Researchers consider the perceived value of the customer as one of the main preconditions for developing the level of customer satisfaction and loyalty. Companies use social media as an important part of their online marketing strategies (Dann, 2010). Social media allow vendors to coordinate internal value creation functions, and thereby, gain a great value in relations with customers (Kaplan \& Haenlein, 2009). Social media also draw the attention of managers. A re- cent survey of executives revealed that almost half of the buyers pay attention to the role of social media and the function of social media strategy used by product and service providers (Agnihotri Kothandaraman, Kashyap \& Singh, 2012). Social media foster and develop mutual enrichment through dialogue, exchange, and participation while also improving the conditions for the participation of consumers and buyers (customers) in the purchasing process. Social media also reduce the coordination and transfer costs by influencing the customer perceived value, as an important marketing strategy through which organizations build relationships with customers (Whelan, Moon, \& Grant, 2013; Agnihotri et al., 2012; Chen \& Lin, 2019). Many companies and organizations are still skeptical about the use of social media to help the marketing function despite buyer enthusiasm for using social media to communicate with companies aimed at purchasing products and services (Chen \& Lin, 2019). In other words, sufficient research has not been done to fully understand and recognize how social media strategies can provide the maximum benefit to an organization. In this regard, the literature identifies factors such as the lack of sufficient knowledge, incomplete perceived value by customers, customer dissatisfaction, cost, and time as challenges related to the social media technology and relevant strategies (Whelan et al., 2013; Chen \& Lin, 2019). Companies in different industries act slowly and are not completely committed to adapting the social media as a strategy to leverage business opportunities due to these challenges (Garcia-Morales, Martín-Rojas \& Lardón-López, 2018). In the current study we sought to examine the role of social media strategies and their relationship with the customer participation intention and the perceived value of customers in the Iranian insurance industry to investigate this research gap. Insurance companies are considered economic enterprises in Iran. The development of new marketing concepts, including marketing with a social media approach, seems to be highly important in this industry. The customer judgment regarding 


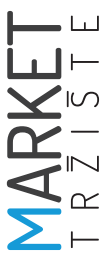

insurance matters nowadays relies on the company's ability to help solve the challenges posed by customers and develop the business. One of the most important of these challenges is customer trust in relation to the messages sent by insurance service providers. Customers receive a large content of promotional messages and therefore have doubts about recognizing values. Companies can increase customer trust by making content transparent on social media to help develop business in the insurance industry. Key opportunities await those companies that are willing in the current conditions to take an effective step in this direction and observe the impact of social media strategy on providing insurance services to the digital generation.

\section{THEORETICAL BACKGROUND}

Today, product marketing has been affected by the growth and development of markets as well as the development of mass media and digital tools, so it has undergone considerable changes (Felix, Rauschnabel \& Hinsch, 2017). Traditional marketing is no longer able to meet the needs or change the tastes and behavior of customers and consumers. Hence, new and innovative marketing methods have won a special place for themselves (Filo, Lock, \& Karg, 2015). Many marketing managers nowadays emphasize the technique of reducing and saving their marketing costs aimed at increasing the competitiveness and competitive advantage (Wang \& Kim, 2017), communication and the basic information system in a technical framework that directs organizational tasks toward meeting management needs (Hajimohammadi, Bazrkar \& Vafaei, 2019). A common technique is to use social media for marketing activities of higher efficiency and coming at a lower cost, which has drawn a lot of attention under the title of social media marketing (Berthon, Pitt, Plangger \& Shapiro, 2012). Social media are able to strategically enhance the mutual communication between companies and customers and connect customers to the company's brand as much as possible (Alalwan, Rana, Dwivedi \& Algharabat, 2017).

\subsection{Social media marketing strategy and customer participation intention}

Weinberg (2009) introduced social media marketing strategy as a process that enables people to promote and advertise their websites, products, or services through online social channels and leads them into a larger society that cannot be realized through tradition methods (Yu, Zo, Kee Choi \& Ciganek, 2013). Social media marketing strategy results in the creation of an interactive network of customers, thereby generating business value for the company and simultaneously internalizing some regulations (Schrader, 2014). The social media environment stimulates customer engagement and participation, given the content provided, and positively affects customer participation intention so that customers are influenced by the information and content provided when browsing websites (Keng \& Ting, 2009). With the advancements of technology and the development of the Internet as well as the formation of online social media a proper infrastructure has now been created for mass communication and transfer of experiences. These environmental changes have transformed the relationship between customers and companies and have formed a new concept known as "customer participation," which can bring significant profitability and financial return for companies according to the researchers (Pansari \& Kumar, 2017). Customer participation is a driver of marketing practice, and there is a high commitment of resources aimed at increasing brand value (Vargo \& Lusch, 2016). It positively influences customer satisfaction and increases the perception of having received higher-quality services (Yim, Chan \& Lam, 2012). Customer participation is taken as the motivated interaction between a company and its customer for co-production, co-creation or participation in brand communities (Dong \& Sivakumar, 2017). Accordingly, the first hypothesis of the research was formulated as follows: 
H1: The social media marketing strategy has a positive impact on the customer participation intention.

\subsection{Social media marketing strategy and perceived value}

Marketing programs based on social media usually focus on generating a content that can encourage the users of social websites to share the desired content on social media while capturing their attention (Kauffman, Lai \& Ho, 2010). Hence, the message of the relevant company, individual, or organization is transmitted from a user to another, so they form a chain (Yadav, Valck, Hennig-Thurau, Hoffman \& Spann, 2013). Customer perceived value seems to be one of the prerequisites for customer satisfaction, trust, commitment, and loyalty. Marketing activities have been founded primarily on customer value (Cheng, Sai, Cheng \& Chen, 2012). The perceived value in marketing is defined in the form of a customer's evaluation of costs and benefits gained from purchasing a product or a service (Kim \& Park, 2013). The results of previous studies suggest that perceived value increases customer satisfaction and future purchases and, in the meantime, the role of social media and strategies developed in that field can be highly decisive. Accordingly, the second hypothesis of the research was formulated as follows:

H2: The social media marketing strategy has a positive effect on customer perceived value.

\subsection{Customer perceived value and customer participation intention}

Customers can create value for the firm directly through their behavior (by making purchases) and indirectly by referring potential customers, influencing current and potential customers on their social network, and providing feedback for improvements (Kumar \& Nanda, 2020). Participation is defined as the level of communication, interaction, partnership, and collaboration between the customer, users or members of the channel, and company during a specific activity
(Tih, Wong, Lynn \& Reilly, 2016). The success of a company depends on its ability to produce a new product that meets the needs and mindset of the customer and creates value for the customer by creating innovation. Innovation serves as a valuable tool for corporate social issues (Vafaei, Bazrkar \& Hajimohammadi, 2019). New markets can also be created through innovation and the introduction of new products, whose success consists in meeting the needs of customers and increasing their satisfaction. Thus, creating an environment in which customers can be involved in the business processes seems to be essential (Shepherd \& Ahmed, 2000). The participation of customers may lead to the superior design of a product or service desired by the company (Pansari \& Kumar, 2017). Customer expectations and perceptions of services form the basis for determining the quality of services (Bazrkar, Milani \& Nasab, 2018). Perceived value originates from customer perceptions, preferences, and evaluations. Customers have expectations of the services provided to them at the time of purchase and consumption; the higher the level at which these expectations are met and satisfied, the higher the value of the product or service as perceived by the customer (France, Merrilees \& Miller, 2016). If that perceived value meets certain conditions, customer participation intent will increase as much (Gligor, Bozkurt \& Russo, 2019). Accordingly, the third hypothesis of the research posits that:

H3: Customer perceived value has a positive effect on customer participation intent.

\subsection{Mediating role of perceived value in the relationship between social media strategy and customer participation intention}

Communication strategies and brand needs have changed with the introduction of social media environment (Hollebeek, Srivastava \& Chen, 2019). By establishing a relationship between a company and its customers through social media, customers can talk about the 
brand, the company's products and services. They can express their opinions, get familiar with new products and services of the company or changes made in the product or service, enjoy other features of the brand, or even advertise the company's products or services through their profiles. All this indicates the importance and necessity of using social media strategy so as to increase customer participation intention (Apaolaza, Hartmann, He, Barrutia \& Echebarria, 2015). The results of previous studies confirm that the perceived value by customers is affected by the level of customer recognition of the organizational brand. It means that companies can use social media technology to enhance the level of customer recognition, thereby strengthening customer participation intention (Dessart, Veloutsou \& Morgan-Thomas, 2015; Gligor et al., 2019). In terms of consumer behavior, value is the key factor in determining individual choice and behavior. The higher the perceived value based on consumers' overall assessment, the higher the loyalty to the service provider they will develop (Sirdeshmukh, Singh \& Sabol, 2002). Increasing this loyalty can have a positive and significant effect on customer participation; in this regard, we can also emphasize the important and decisive role of social media marketing strategies. On the other hand, value comes in many forms and from many sources, such as product utility, quality, image (formed by advertising and promotional activities), availability, as well as additional services. Understanding the impact and role of the types of value perceived by the customer in the relationship between social media marketing strategies and customer participation intention can be very crucial in the success of service organizations, including insurance. Accordingly, the fourth research hypothesis was formulated as follows:

H4: The social media marketing strategy positively affects customer participation intention through customer perceived value.

\subsection{Research model}

We reviewed previous research and studies on social media strategy, value perceived by customers, and customer participation intention in light of the main goal of the present study, namely, to examine the impact of social media marketing strategy on participation intent considering the mediating role of perceived value of customers in the Iranian insurance industry. Accordingly, the conceptual model of the research (shown in Figure 1 below) was designed to investigate the relationship between the independent and dependent variables of the research and analyze the effect rate of the mediating variable of customer perceived value on the relationship between these two variables.

\section{FIGURE 1: Conceptual research model}

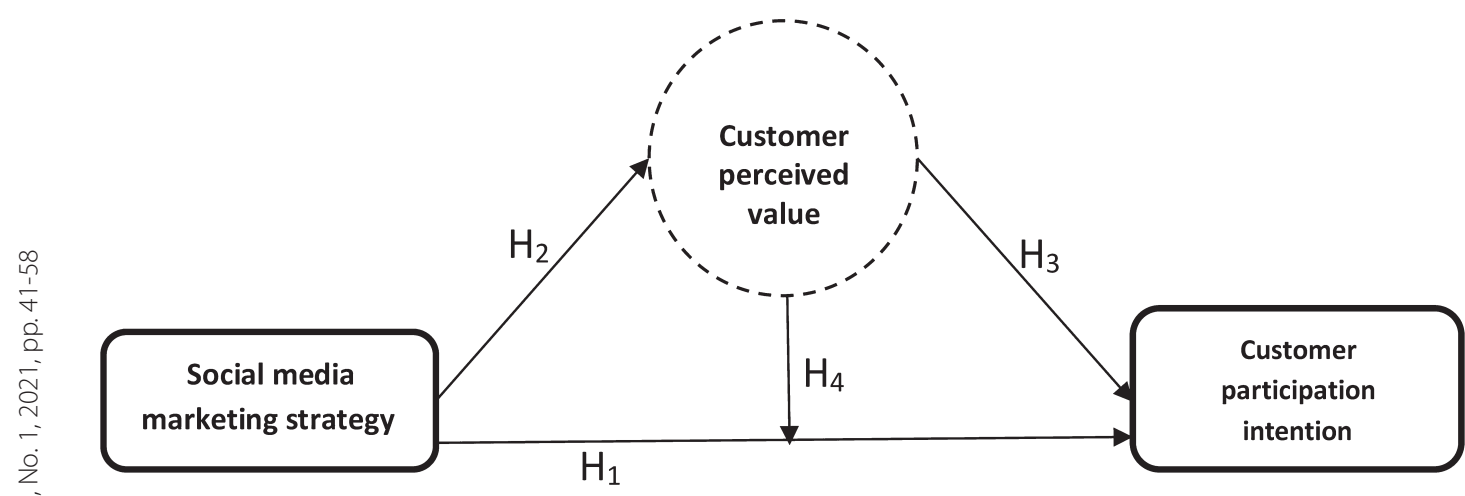

Source: Authors' own research. 


\section{METHODOLOGY}

As this study has focused on the relationship between social media marketing strategy and customer participation intention in the insurance industry of Iran according to the role of perceived value of customers, it can be classified as an applied research study in terms of the methodology, combining the objective and the descriptive survey method.

\subsection{Data collection}

We used a questionnaire to collect data for the research. All the questions were evaluated on a five-point Likert scale, ranging from 1 (very weak) to 5 (very strong). Based on the conceptual research model that includes an exogenous variable, i.e., the social media marketing strategy, we adapted the questions from those used in the studies by Towner and Dulio (2011) and Keegan and Rowley (2017) to measure the exogenous variables. Four questions in the questionnaire were designed to evaluate the social media marketing strategy variable. The results of the Cronbach's alpha test, used to measure model reliability, showed the value obtained for each item of this variable to be higher than 0.7 , so the reliability of the exogenous variable was confirmed. The results are shown in Table 1. The questions used in the research by Chen and Shen (2015) and Chen and Lin (2019) were used to collect data on the variables of customer participation intention and customer perceived value, respectively, as endogenous and mediating variables of the research. The number of questions used to assess customer participation intention was 6 , while 7 questions assessed the customer perceived value variable. The results of the Cronbach's alpha test for all items related to the variables of customer participation intention rate and customer perceived value were above 0.7 , which indicates a very high confidence for these two variables. The results are shown in Table 1.

The statistical population of this study consisted of companies active in the Iranian insurance industry, which is estimated to number $30 \mathrm{com}$ panies. We randomly selected 15 companies to form the sample for the survey. A simple random sample is a subset of the statistical population in which each member of the subset has an equal probability of being chosen (Kadilar \& Cingi, 2006). In fact, this method was used to give all companies an equal chance of being selected. Then in the next step, using the databases of the studied companies, the respondents to the questionnaires were identified by a judgmental method and based on the opinions of senior IT and marketing managers of the insurance companies. Such purposive or judgmental sampling is a strategy in which particular settings, persons, or events are selected deliberately in order to provide important information that cannot be obtained from other choices (Maxwell, 1996). The respondents to the questionnaires were indeed the customers who had become acquainted with insurance services through social media in the last year and who communicated with insurance companies through social media. Their number was estimated as 1,840 individuals in the initial surveys. Given the high number of these people, the Cochran formula was applied, as one of the most widely used methods for determine the minimum sample size from a statistical population (Tejada \& Punzalan, 2012). A total of 318 subjects were finally selected for the sample and the questionnaire was distributed among them electronically. Within two weeks from the time they were sent, 297 completed questionnaires were collected. It should be noted that the return rate of the completed questionnaire was estimated to be 0.93 , indicating that more than $90 \%$ of the respondents have answered the questions, which is an acceptable rate. Besides the questions related to the independent, dependent, and mediating variables of the research, the questionnaires also included some questions about the demographic characteristics of the respondents (customers), relating related to their age, gender, and education level. An analysis of data related to these features showed the age of 115 of 297 respondents (39\%) to be in the range of 20 to 30 years, for 109 
of them (37\%) in the range of 30 to 40 , while 47 respondents (16\%) were aged between 40 and 50 , and $26(8 \%)$ were over 50 years old. Of the 297 respondents, 178 (60\%) were male and 119 (40\%) were female. The data on their education level showed that 171 respondents (57\%) had a bachelor's degree and lower, 92 had a master's degree (31\%), and 34 had a doctorate (12\%). The results of descriptive statistics of data collected through a questionnaire are shown in Table 1.

TABLE 1: Descriptive statistics results

\begin{tabular}{|c|c|c|c|c|c|}
\hline Concept & $\begin{array}{c}\text { Variable } \\
\text { Name }\end{array}$ & Item & Mean & $\begin{array}{l}\text { Standard } \\
\text { deviation }\end{array}$ & $\begin{array}{c}\text { Cronbach's } \\
\text { alpha }\end{array}$ \\
\hline \multirow{4}{*}{$\begin{array}{l}\text { Social media } \\
\text { marketing } \\
\text { strategy }\end{array}$} & SMMS1 & $\begin{array}{l}\text { Gaining new customers leads to market } \\
\text { leadership. }\end{array}$ & 3.99 & 0.297 & 0.79 \\
\hline & SMMS2 & $\begin{array}{l}\text { Serving existing customers and } \\
\text { maintaining current relationships is the } \\
\text { focus of managers. }\end{array}$ & 4.01 & 0.269 & 0.82 \\
\hline & SMMS3 & $\begin{array}{l}\text { Acquiring information from the market } \\
\text { and knowing the customer is the focus } \\
\text { of managers. }\end{array}$ & 4.03 & 0.225 & 0.84 \\
\hline & SMMS4 & $\begin{array}{l}\text { Managing customers and obtaining } \\
\text { information from them is the focus of } \\
\text { managers. }\end{array}$ & 3.99 & 0.228 & 0.76 \\
\hline \multirow{6}{*}{$\begin{array}{l}\text { Customer } \\
\text { participation } \\
\text { intention }\end{array}$} & CPI1 & $\begin{array}{l}\text { You want to give your information to } \\
\text { others when they want to go to the } \\
\text { bank for services. }\end{array}$ & 3.91 & 0.319 & 0.71 \\
\hline & CPI2 & $\begin{array}{l}\text { You want to share with friends your } \\
\text { positive experiences with receiving } \\
\text { services from the bank. }\end{array}$ & 4.15 & 0.331 & 0.79 \\
\hline & CPI3 & $\begin{array}{l}\text { You want to introduce a service that is } \\
\text { worth buying to others. }\end{array}$ & 3.81 & 0.319 & 0.75 \\
\hline & CPI4 & $\begin{array}{l}\text { When buying services, you want to use } \\
\text { the experience of your friends. }\end{array}$ & 3.78 & 0.296 & 0.84 \\
\hline & CPI5 & $\begin{array}{l}\text { You want to ask others to share their } \\
\text { shopping experiences with you. }\end{array}$ & 3.98 & 0.367 & 0.73 \\
\hline & CPI6 & $\begin{array}{l}\text { You want to provide the services that } \\
\text { your friends offer you. }\end{array}$ & 4.08 & 0.337 & 0.77 \\
\hline \multirow{7}{*}{$\begin{array}{l}\text { Customer } \\
\text { perceived } \\
\text { value }\end{array}$} & CPV1 & $\begin{array}{l}\text { The services received from the bank in } \\
\text { relation to the price are valuable to you. }\end{array}$ & 4.09 & 0.479 & 0.81 \\
\hline & CPV2 & $\begin{array}{l}\text { You feel that the services delivered by } \\
\text { the bank are valuable. }\end{array}$ & 3.68 & 0.463 & 0.87 \\
\hline & CPV3 & $\begin{array}{l}\text { You feel that the services delivered by } \\
\text { the bank are worth the cost. }\end{array}$ & 4.12 & 0.442 & 0.88 \\
\hline & CPV4 & $\begin{array}{l}\text { Wants to visit the bank again to receive } \\
\text { services. }\end{array}$ & 4.29 & 0.391 & 0.83 \\
\hline & CPV5 & $\begin{array}{l}\text { You want to explain the value of } \\
\text { receiving bank services to others. }\end{array}$ & 3.77 & 0.446 & 0.78 \\
\hline & CPV6 & $\begin{array}{l}\text { You feel that the behavior of bank } \\
\text { employees is valuable to customers. }\end{array}$ & 3.88 & 0.451 & 0.80 \\
\hline & CPV7 & $\begin{array}{l}\text { You feel that bank managers are trying } \\
\text { to provide useful services to customers. }\end{array}$ & 4.07 & 0.419 & 0.85 \\
\hline
\end{tabular}

Source: Authors' own calculations. 


\subsection{Data analysis method}

The partial least squares structural equation modeling (PLS-SEM) method was used in this study to analyze the data, fitness of the research conceptual model, and test the hypotheses (Aramoon, Aramoon \& Bazrkar, 2020). The PLS modeling is widely used in various fields, including management sciences (Wen, 2010). The LISREL approach focuses on covariance maximization and the PLS modeling focuses on variance maximization. As a variance-based approach PLS requires fewer conditions than the techniques like LISREL and AMOS, similar to structural equations (Liljander, Polsa \& van Riel, 2009). For example, unlike LISREL, the PLS path modeling is more tailored for real-world applications; especially when the models are more complex, it is more desirable to use this approach (Wen, 2010). The PLS path modeling method is preferred over covariance-based techniques such as LISREL in the cases where the study aims to analyze causal relationships and predictions (Hair, Hult, Ringle \& Sarstedt, 2014). The main reason for PLS-SEM's attractiveness is that the method allows researchers to estimate very complex models with many constructs and indicator variables, especially when prediction is the goal of the analysis. Furthermore, PLS-SEM generally allows for much flexibility in terms of data requirements and the specification of relationships between constructs and indicator variables (Sarstedt, Ringle \& Hair, 2017; Ringle, Sarstedt, Mitchell \& Gudergan, 2020). This algorithm consists of two main parts when evaluating the model fit and testing the research hypotheses. The first part, i.e., model fitting, is done in three steps: fitting of measurement models, structural model fitting, and overall model fitting. Hence, the accuracy of the relationships in the measurement models is ensured first using the reliability and validity criteria. Then, the existing relationships in the structural section are examined. In the final stage, the overall fit of the research model is examined.

\subsubsection{Measurement model fit}

The fit of measurement models involves examining the reliability and validity of the research constructs. The Fornell-Larcker criterion is a standard approach applied to assess discriminant validity in covariance-based SEM (Henseler, Hubona \& Ray, 2016). Fornell and Larcker (1981) proposed three criteria for evaluating the reliability of the constructs:

A. the reliability of each of the research items,

B. the combined reliability of each research construct,

C. the average variance extracted (AVE) or convergent validity.

The three criteria of reliability, convergent validity, and divergent validity are also used to examine the measurement model fit according to the SEM algorithm. The results are described below.

\section{Reliability}

Reliability is evaluated through the methods of measuring factor loading, Cronbach's alpha, and combined reliability. Factor load is a numerical value that determines the intensity of the relationship between a hidden variable (structure) and a relevant explicit variable (index) during the path analysis process (Taber, 2018). The higher the factor load value of an index concerning a given structure, the greater the role the index plays in explaining that structure. Cronbach's alpha is known as the criterion to measure reliability and is a good measure for internal evaluation. Internal reliability indicates the degree of correlation between a structure and its indicators. Combined reliability was introduced by Werts, Linn and Joreskog (1974); its advantage over Cronbach's alpha is that the reliability of structures (constructs) is calculated not in absolute terms but according to the correlation of their structures with each other (Li \& Zhang, 2011). The combined reliability value higher than 0.7 for each structure indicates good internal reliability for measurement mod- 
els, while the value lower than 0.6 indicates the absence of reliability.

\section{Validity}

The validity criterion is examined through convergent validity and divergent validity in the structural equation modeling method (Henseler et al., 2016).

a) Convergent validity: One aspect of construct validity includes the testing of hypotheses about the relationships of scores between the scales that appear to measure similar dimensions or factors. This is also referred to as convergent validity (Abma Rovers \& van der Wees, 2016). After examining three reliability criteria, the convergent validity is considered the second criterion of the measurement model fit. The convergent validity criterion represents the average variance shared between each structure with its indices; the value of this criterion higher than 0.4 is considered to be appropriate.

b) Divergent validity: The third criterion for evaluating the measurement model fit in PLS analyses is divergent validity. This criterion is assessed by two methods of cross-factor loading and Fornell-Larcker method. According to this method, divergent validity will be confirmed if the square of the average variance extracted for each structure is more than the correlation between the structures. In this approach, the issue is examined by a matrix whose cells contain the correlation coefficients between the structures and the root of the convergent validity values related to each structure.

\subsubsection{Structural model fit}

In the structural equation modeling method, the fit of the research structural model is examined after the measurement model fit. The relationships of the latent variables (structures) with each other are analyzed in examining the structural model and the criteria of significance coefficients $t$, the coefficient of determination of the model, $R^{2}$, and the redundancy criterion are used to determine the model fit. The t-values greater than 1.96 suggest the accuracy of the relationships between the structures, confirming the research hypotheses at a 95\% confidence level. Evaluating the coefficients of determination $\left(R^{2}\right)$ related to endogenous latent variables (dependent variable) of the model is the second necessary criterion for measuring the structural model fit. This criterion is used to connect the measurement part and the structural part of the structural equation modeling and represents the effect of an exogenous (independent) variable on an endogenous (dependent) variable. It should be noted that the $R^{2}$ values of the model are calculated only for the endogenous structures of the model; the value of this criterion is equal to zero in the case of the model exogenous structures. Chin (2010) introduced three values of $0.19,0.33$, and 0.67 as criteria for weak, moderate, and strong $R^{2}$ respectively. Next, the approximate model fit may also be determined to assess the discrepancy between the model-implied and the empirical correlation matrix. This is particularly relevant if the discrepancy is significant. Currently, the only approximate model fit criterion implemented for PLS path modeling is the standardized root mean square residual (SRMR) (Henseler et al., 2016). A value of 0 for SRMR would indicate a perfect fit and generally, an SRMR value less than 0.05 indicates an acceptable fit. A recent simulation study shows that even entirely correctly specified model can yield SRMR values of 0.06 and higher.

\section{Stone-Geisser $\left(Q^{2}\right)$}

This criterion determines the predictive power of the model. The models with an acceptable structural fit should have the ability to predict the indicators related to the endogenous structures of the model. Thus, if the relationships between the structures in a model are properly defined, the structures can sufficiently influence each other's indices, and thereby, the hypotheses are confirmed accurately. Henseler and others (2016) 
determined the three values of $0.02,0.15$, and 0.35 , respectively as weak, moderate, and strong predictions regarding the intensity of the model predictive power for endogenous structures.

\subsubsection{Overall research model fit}

The goodness-of-fit criterion is used to examine the fit of the overall model according to the structural equation modeling algorithm, which controls both measurement and structural parts. This criterion was introduced by Tenenhaus, Amatos and Esposito Vinzi (2004) and is calculated according to the following equation:

$$
\mathrm{GOF}=\sqrt{\text { average (Communality) } \times \text { averageR2 }}
$$

This criterion is defined as weak, moderate, and strong with three values of 0.01, 0.25, and 0.36, respectively (Wetzels Odekeken-Schroder \& Van Oppen, 2009).

\section{RESULTS}

In this study, the structural equation modeling method in Smart-PLS 3.2.7 software was used for the purpose of achieving the research goal and testing the research hypotheses. Also, two basic methodological elements of the measurement and structural models were considered in order to do so. The PLS-SEM technique is currently used in many management studies, including marketing (Hair et al., 2014).

\subsection{Results of the measurement model evaluation}

Measurement models are used to estimate the relationships between each latent variable and its associated indicators (Mousa \& Othman, 2020). The reliability and validity indices of measurement models are used to evaluate the fit of the measurement models. The three criteria of load factor coefficients, Cronbach's alpha, and combined reliability were used to assess the reliability. On the other hand, two criteria of convergent validity and divergent validity were applied to examine the validity. The results of evaluating the reliability criteria (Cronbach's alpha and combined reliability), convergent validity, and the results of measuring the factor loading of the research variables (Table 2) show the values obtained for factor loading higher than 0.5, Cronbach's alpha higher than 0.7, and combined reliability higher than the determined set criterion of 0.7. Also, the result obtained according to the convergent validity criterion indicates that the convergent validity values of all research structures are higher than the standard value of 0.5. The Fornell-Larcker (1981) method was used to assess the divergent validity of the research structures. According to the results (Table 3), the divergent validity of the research structures is confirmed since the square of the average variance extracted for each structure was found to be higher than the correlation obtained between the structures. These results indicate the appropriate internal stability for the measurement model and confirm the model fit. As a result, the measurement model has been confirmed.

TABLE 2: Results of factor loading coefficients, Cronbach's alpha, CR, and AVE measurement

\begin{tabular}{|c|c|c|c|c|c|}
\hline $\begin{array}{l}\text { Struc- } \\
\text { ture }\end{array}$ & Item & $\begin{array}{l}\text { Fac- } \\
\text { tor } \\
\text { load- } \\
\text { ing }\end{array}$ & $\begin{array}{l}\text { Cron- } \\
\text { bach's } \\
\text { alpha }\end{array}$ & $\begin{array}{l}\text { Com- } \\
\text { bined } \\
\text { reli- } \\
\text { ability }\end{array}$ & $\begin{array}{l}\text { Con- } \\
\text { ver- } \\
\text { gent } \\
\text { validity }\end{array}$ \\
\hline \multirow{4}{*}{\begin{tabular}{|l|} 
Social \\
media \\
mar- \\
keting \\
strategy \\
\end{tabular}} & SMMS1 & 0.623 & \multirow{4}{*}{0.816} & \multirow{4}{*}{0.864} & \multirow{4}{*}{0.652} \\
\hline & SMMS2 & 0.739 & & & \\
\hline & SMMS3 & 0.633 & & & \\
\hline & SMMS4 & 0.637 & & & \\
\hline \multirow{6}{*}{\begin{tabular}{|l|} 
Cus- \\
tomer \\
partici- \\
pation \\
inten- \\
tion \\
\end{tabular}} & CPI1 & 0.619 & \multirow{6}{*}{0.860} & \multirow{6}{*}{0.867} & \multirow{6}{*}{0.631} \\
\hline & CPI2 & 0.622 & & & \\
\hline & $\mathrm{CPI} 3$ & 0.724 & & & \\
\hline & CPI4 & 0.809 & & & \\
\hline & $\mathrm{CPI} 5$ & 0.657 & & & \\
\hline & CPI6 & 0.728 & & & \\
\hline \multirow{7}{*}{$\begin{array}{l}\text { Custom- } \\
\text { er per- } \\
\text { ceived } \\
\text { value }\end{array}$} & CPV1 & 0.655 & \multirow{7}{*}{0.865} & \multirow{7}{*}{0.933} & \multirow{7}{*}{0.655} \\
\hline & CPV2 & 0.879 & & & \\
\hline & CPV3 & 0.552 & & & \\
\hline & CPV4 & 0.515 & & & \\
\hline & CPV5 & 0.617 & & & \\
\hline & CPV6 & 0.661 & & & \\
\hline & CPV7 & 0.519 & & & \\
\hline
\end{tabular}

Source: Authors' own calculations.

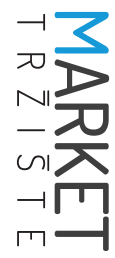


TABLE 3: Results of divergent validity evaluation of structures

\begin{tabular}{|l|c|c|c|}
\hline & $\begin{array}{c}\text { Social media } \\
\text { marketing strategy }\end{array}$ & $\begin{array}{c}\text { Customer } \\
\text { participation intention }\end{array}$ & $\begin{array}{c}\text { Customer } \\
\text { perceived value }\end{array}$ \\
\hline $\begin{array}{l}\text { Social media marketing } \\
\text { strategy }\end{array}$ & $\mathbf{0 . 8 0 7}$ & $\mathbf{0 . 7 9 4}$ & \\
\hline $\begin{array}{l}\text { Customer participation } \\
\text { intention }\end{array}$ & 0.754 & 0.712 & $\mathbf{0 . 8 0 9}$ \\
\hline $\begin{array}{l}\text { Customer perceived } \\
\text { value }\end{array}$ & 0.690 & & \\
\hline
\end{tabular}

Source: Authors' own calculations.

\subsection{Results of evaluating the structural model fit}

\subsubsection{T-value significance coefficients}

The t-values greater than 1.96 indicate the accuracy of the relationship between the structures, and thereby, confirm the research hypotheses at the level of 95\%. The results show the t-value for social media marketing strategy and customer participation intention dimension to be equal to 3.120 , with that of the social media marketing strategy and customer perceived value equaling 13.612, and of the customer perceived value and customer participation intention at 3.458. Since all the t-values are higher than 1.96, the constructs are significant, the structural research model is fit, and also the research hypotheses have been confirmed.

\subsubsection{R-square criterion}

The second necessary criterion for examining the structural model fit is to evaluate the coefficients of determination $\left(R^{2}\right)$ related to the endogenous (dependent) variables of the model. The values of this coefficient can be seen in Figure 2. According to the values obtained for the variables of customer participation intention and customer perceived value equal to 0.725 and 0.658 , respectively, the goodness of fit of the structural model is confirmed.

FIGURE 2: Values of path coefficients, factor loading, and $\mathrm{R}^{2}$

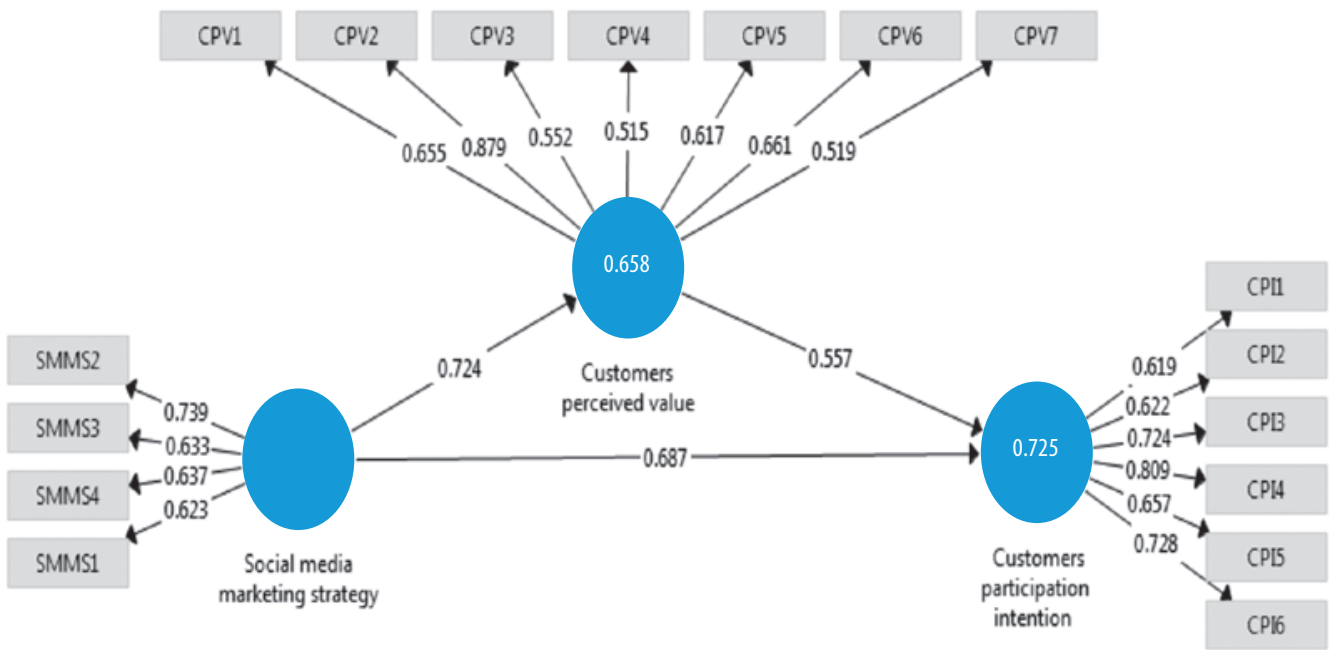

Source: Authors' own calculations. 


\subsubsection{Standardized root mean square residual (SRMR)}

The results of the standardized root mean square residual (SRMR) study showed the value obtained to be less than 0.05 , that is, equal to 0.02 . As a result, the model fits.

\subsubsection{Stone-Geisser criterion $\left(Q^{2}\right)$}

The $\mathrm{Q}^{2}$ value of the two endogenous constructs of the research model - customer participation intention and customer perceived value - was found to be 0.290 and 0.257 , respectively. This suggests a strong predictive power of the model and once again confirms the goodness of the fit of the structural research model.

\subsubsection{Results of evaluation of the overall model fit based on GoF}

Regarding the goodness-of-fit (GoF), the "average communality" refers to the average of the shared values of each structure, where the average $R^{2}$ is the mean value of $R^{2}$ values of the endogenous structures of the model (Wetzels et al., 2009).

$$
\mathrm{GoF}=\sqrt{0.243 \times 0.691}=0.410
$$

Based on the result, the value of the GoF criterion is equal to 0.410 , which indicates the strong overall fit of the model.

\subsection{Research hypotheses testing}

The research hypotheses were tested by examining the significance coefficients (t-values) of each dimension and of the path coefficients. If the value of significant coefficients of each of the paths is more than 1.96, the relevant path is significant at the 95\% confidence level and the associated hypothesis is confirmed. The results of hypotheses testing are reported in Table 4.

TABLE 4: Results of hypotheses testing

\begin{tabular}{|c|c|c|c|c|c|}
\hline Hypothesis & Path & Path coefficient & t-value & P-value & Test result \\
\hline \multicolumn{6}{|l|}{ Direct effect } \\
\hline $\mathrm{H} 1$ & $\mathrm{SMMS} \rightarrow \mathrm{CPI}$ & 0.687 & 3.120 & 0.002 & supported \\
\hline $\mathrm{H} 2$ & SMMS $\rightarrow$ CPV & 0.724 & 13.612 & 0.000 & supported \\
\hline $\mathrm{H} 3$ & $\mathrm{CPV} \rightarrow \mathrm{CPI}$ & 0.557 & 3.458 & 0.001 & supported \\
\hline \multicolumn{6}{|c|}{ Mediator effect } \\
\hline $\mathrm{H} 4$ & $\mathrm{SMMS} \rightarrow \mathrm{CPV} \rightarrow \mathrm{CPI}$ & 0.403 & 3.188 & 0.002 & supported \\
\hline
\end{tabular}

Source: Authors' own calculations.

Based on the values obtained in Table 4, one can conclude that the social media marketing strategy has a positive and significant effect on customer participation intention as well as on customer perceived value. Also, the results of testing the fourth hypothesis suggest that the perceived value variable plays a mediating role in the relationship between the social media marketing strategy and customer participation intention, and also that the social media marketing strategy has a positive impact on customer participation intention through customer perceived value.

\section{CONCLUSION}

The main goal of this research study was to examine the impact of the social media marketing strategy on customer participation intention also considering the mediating role of perceived value of customers in the Iranian insurance industry. Based on the results, one can say that the studied companies can have a positive impact on their customer participation intention by adopting appropriate social media marketing strategies to improve their marketing performance. Among these strategies, we can men- 


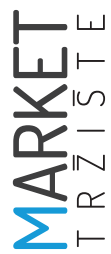

tion the content production strategy including the customer interaction approach and the strategy aimed at increasing brand awareness. Subsequently, we analyzed the results of the hypotheses. The result of testing of the first research hypothesis indicated that the social media marketing strategy has a positive effect on the participation intention of insurance industry customers and that it directly predicts 0.687 of changes related to the customer participation intention. Accordingly, one can say that insurance companies can strengthen the social media environment by developing and using appropriate strategies to provide proper conditions for further interaction with customers. Such a positive interaction could lead to a strengthening of customer participation and engagement in the implementation of medium-term and long-term plans of insurance companies. The literature reviews showed the result of testing this hypothesis to be consistent with the results of the study by Ashley and Tuten (2015) and those obtained by Osei-Frimpong (2019). The result of testing of the second research hypothesis indicated that the social media marketing strategy has a positive effect on the perceived value of insurance industry customers and that it directly predicts 0.724 of changes related to the customer perceived value. Accordingly, one can say that, as perceived value increases customer satisfaction and future purchases, the role of social media and strategies developed in that field can be highly decisive. As indicated by literature reviews, the result of testing of this hypothesis are consistent with those obtained by Carlson, O'Cass and Ahrholdt (2015), Seo and Park (2018), and Chen and Lin (2019) in their studies. The testing of the third research hypothesis found the perceived value of customers to have a positive effect on customer participation intention, with the perceived value of customers directly predicting 0.557 of changes related to the customer participation intention. Accordingly, it is recommended that managers in the insurance industry examine and analyze the perceived values of their customers resulting from their performance in transmitting these values to strengthen their customer participation intention. Their failure to pay attention to the values perceived by customers while focusing merely on traditional marketing may lead to a situation in which they can no longer meet the needs and keep with change in the tastes and behaviors of customers and consumers. Given that customers are not only very sensitive to the values signaled by organizations but are also influenced by them, this can have both positive and negative effects on the customer participation intention. The reviews of previous research studies show the results of testing of this hypothesis to be consistent with those of Stone, Woodcock, Ekinci, Aravopoulou and Parnell (2019). The testing of the fourth hypothesis found that the customer perceived value variable plays a mediating role in the relationship between the social media marketing strategy and customer participation intention, where the social media marketing strategy predicts 0.433 of changes related to the participation intention of customers through customer perceived value. Accordingly, it is recommended that managers of Iranian insurance companies pay more attention to the issue of customer perceived value in their organization's plans and take steps to convey positive values so that the goal of promoting customer participation can be achieved. Since customer perceived value is one of the prerequisites for customer satisfaction, trust, commitment, as well as loyalty, paying attention to the transfer of appropriate values will bring many benefits, including increased customer participation.

While the results of the hypothesis test in this study were found to be in line with those of many researchers, including Ashley and Tuten (2015), Osei-Frimpong (2019), Carlson and others (2015), Seo and Park (2018), and Chen and Lin (2019), the results of this research are also unique in terms of the impact they have on the industry under scrutiny (Iran's insurance industry). They are significant from the perspective of the Iranian insurance companies, which can apply them to better understand the needs, wants, and preferences of their customers so that they can 
satisfy customer needs while using social media marketing strategies to improve their own marketing performance. Also, these companies can improve their marketing capabilities through a correct understanding of the social network marketing performance in the Iranian insurance industry and the impact of such strategies on the participation of their customers. Proper use of this tool can make the environment in the insurance industry more competitive and allow companies to increase their financial strength. By adopting and implementing effective market orientation practices, which would include the formulation of effective social media marketing strategies to enhance customer engagement, insurance companies and their brokers may increase their growth potential and improve their long-term performance.

\subsection{Research limitations and suggestions for future research}

This research study faced some limitations during the implementation process. Given that it is an exploratory study, the research findings are lim- ited to the sample size, and thus, the results may change in the case of changes in the sample. Besides, different opinions about the research topic among respondents in the sample can somewhat affect the research results. The sample included Iranian insurance companies, so the results obtained are specific to these companies and cannot be generalized to all organizations or companies. However, it would be worth applying the subject of this study to other organizations and manufacturing and service companies in future research. With the impact of social media marketing strategy on customer participation intention in the insurance industry examined here and given the importance of customer satisfaction in the insurance industry, it is suggested that the impact of social media marketing strategy on the variable of customer satisfaction be explored in future research. We considered the perceived value variable as a mediating variable in this study. Accordingly, it is suggested that researchers explore the mediating role of other variables, including customer satisfaction and customer loyalty in future research.

\section{References}

1. Abma, I. L., Rovers, M., \& van der Wees, P. J. (2016). Appraising convergent validity of patient-reported outcome measures in systematic reviews: Constructing hypotheses and interpreting outcomes. BMC Research Notes, 9, 226, 1-5.

2. Agnihotri, R., Kothandaraman, P., Kashyap, R., \& Singh, R. (2012). Bringing "social" into sales: The impact of salespeople's social media uses on service behaviors and value creation. Journal of Personal Selling \& Sales Management, 22(3), 333-348.

3. Alalwan, A. A., Rana, N. P., Dwivedi, Y. K., \& Algharabat, R. (2017). Social Media in Marketing: A Review and Analysis of the Existing Literature. Telematics and Informatics, 34(7), 1177-1190.

4. Apaolaza, V., Hartmann, P., He, J., Barrutia, J., \& Echebarria, E. (2015). Shanghai adolescents' brand interactions on the Chinese Social Networking Site Qzone: A Uses and Gratifications Approach. Revista Española de Investigation de Marketing ESIC, 19(1), 62-70.

5. Aramoon, V., Aramoon, E., \& Bazrkar, A. (2020). Investigating the Effect of Implementing the Lean Six Sigma on Organizational Performance Based on the Mediating Role of Strategic Knowledge Management with Structural Equation Modeling Approach. NAVUS - Revista de Gestão e Tecnologia, 10, 1-16.

6. Ashley, C., \& Tuten, T. (2015). Creative Strategies in Social Media Marketing: An Exploratory Study of Branded Social Content and Consumer Engagement. Psychology and Marketing, 32(1), 15-27.

7. Bazrkar, A., Milani, S. M., \& Nasab, S. A. (2018). The relationship between management commitment to service quality and organizational outputs considering the mediating role of effective 
participation of employees in banking services. International Journal for Quality Research, 12(3), 625-638.

8. Berthon, P. R., Pitt, L. F., Plangger, K., \& Shapiro, D. (2012). Marketing Meets Web 2.0, Social Media, and Creative Consumers: Implications for International Marketing Strategy. Business Horizons, 55(3), 261-271.

9. Carlson, J., O'Cass, A., \& Ahrholdt, D. (2015). Assessing customers perceived value of the online channel of multichannel retailers: A two country examination. Journal of Retailing and Consumer Services, 27, 90-102.

10. Chang, Y. T., Yu, H., \& Lu, H. P. (2015). Persuasive messages, popularity cohesion, and message diffusion in social media marketing. Journal of Business Research, 68(4), 777-782.

11. Cheng, S., Sai, M., Cheng, N., \& Chen, K. (2012). Predicting intention to purchase on group buying website in Taiwan. Online Information Review, 36(5), 698-712.

12. Chen, J., \& Shen, X.L. (2015). Consumers' decisions in social commerce context: An empirical investigation. Decision Support Systems, 79, 55-64.

13. Chen, S. C., \& Lin, C. P. (2019). Understanding the effect of social media marketing activities: the mediation of social identification, perceived value, and satisfaction. Technological Forecasting \& Social Change, 140, 22-32.

14. Chin, W. W. (2010). How to Write Up and Report PLS Analyses. In: V. Esposito Vinzi, W. W. Chin, J. Henseler \& H. Wang, (Eds.), Handbook of Partial Least Squares: Concepts, Methods and Applications (pp. 655-690). Heidelberg: Springer.

15. Dann, S. (2010). Redefining social marketing with contemporary commercial marketing definitions. Journal of Business Research, 63(2),147-153.

16. Dessart, L., Veloutsou, C., \& Morgan-Thomas, A. (2015). Consumer engagement in online brand communities: A social media perspective. Journal of Product \& Brand Management, 24(1), 28-42.

17. Dong, B., \& Sivakumar, K. (2017). Customer participation in services: Domain, scope, and boundaries. Journal of the Academy of Marketing Science, 45, 944-965.

18. Ferreira, J. B., da Rocha, A., \& Ferreira da Silva, J. (2014). Impacts of technology readiness on emotions and cognition in Brazil. Journal of Business Research, 67(5), 865-873.

19. France, C., Merrilees, B., \& Miller, D. (2016). An integrated model of customer-brand engagement: Drivers and consequences. Journal of Brand Management, 23(2), 119-136.

20. Felix, R., Rauschnabel, P., \& Hinsch, C. (2017). Elements of strategic social media marketing: A holistic framework. Journal of Business Research, 70, 118-126.

21. Filo, K., Lock, D., \& Karg, A. (2015). Sport and social media research: A review. Sport Management Review, 18(2), 166-181.

22. Fornell, C., \& Larcker, D. (1981). Structural equation models with unobservable variables and measurement error. Journal of Marketing Research, 18(1), 39-50.

23. Garcia-Morales, V. J., Martín-Rojas, R., \& Lardón-López, M. S. (2018). Influence of social media technologies on organizational performance through knowledge and innovation. Baltic Journal of Management, 13(3), 345-367.

24. Gligor, D., Bozkurt, S., \& Russo, I. (2019). Achieving customer engagement with social media: A qualitative comparative analysis approach. Journal Business Research, 101, 59-69.

25. Hair, J. F., Hult, G. T. M., Ringle, C., \& Sarstedt, M. (2014). A primer on partial least squares structural equation modeling (PLS-SEM). Thousand Oaks, CA: Sage Publications.

26. Hajimohammadi, M., Bazrkar, A., \& Vafaei, S. (2019). Creating a Sustainable Competitive Advantage for Organizations Through the Implementation of Knowledge Management with the help of Modern Information Technology. IJERI: International Journal of Educational Research and Innovation, 12, 203-216. 
27. Henseler, J., Hubona, G., \& Ray, P. A. (2016). Using PLS path modeling in new technology research: updated guidelines. Industrial Management \& Data Systems, 116(1), 2-20.

28. Hollebeek, L. D., Srivastava, R. K., \& Chen, T. (2019). S-D logic-informed customer engagement: integrative framework, revised fundamental propositions, and application to CRM. Journal of the Academy of Marketing Science, 47, 161-185.

29. Kadilar, C., \& Cingi, H. (2006). An improvement in estimating the population mean by using the correlation coefficient. Hacettepe Journal of Mathematics and Statistics, 35(1), 103-109.

30. Kauffman, R., Lai, H., \& Ho, C. (2010). Incentive mechanisms, fairness and participation in online group-buying auctions. Electronic Commerce Research and Applications, 9(3), 249-262.

31. Kaplan, A. M., \& Haenlein, M. (2009). Consumers, companies, and virtual social worlds: A qualitative analysis of Second Life. Advances in Consumer Research, 36(1), 873-874.

32. Keegan, B. J., \& Rowley, J. (2017). Evaluation and decision making in social media marketing. Management Decision, 55(1), 15-31.

33. Keng, C. J., \& Ting, H. Y. (2009). The acceptance of blogs: using a customer experiential value perspective. Internet Research, 19(5), 479-495.

34. Kohli, C., Suri, R., \& Kapoor, A. (2015). Will social media kill branding?. Business Horizons, 58(1), 35-44.

35. Kim, S., \& Park, H. (2013). Effects of various characteristics of social commerce (s-commerce) on consumers' trust and trust performance. International Journal of Information Management, 33(2), 318-332.

36. Kumar, V., \& Nanda, P. (2020). Social Media as a Tool in Higher Education: A Pedagogical Perspective. In L. A. Tomei \& D. D. Carbonara (Eds.), Handbook of Research on Diverse Teaching Strategies for the Technology-Rich Classroom (pp. 239-253). Boston, MA: IGI Global.

37. Li, G., \& Zhang, K. (2011). A combined reliability analysis approach with dimension reduction method and maximum entropy method. Structural and Multidisciplinary Optimization, 43, 121-134.

38. Liljander, V., Polsa, P., \& van Riel, A. (2009). Modelling consumer responses to an apparel store brand: Store image as a risk reducer. Journal of Retailing and Consumer Services, 16(4), 281-290.

39. Maxwell, J. A. (1996). Qualitative Research Design: An Interactive Approach. Thousand Oaks, CA: Sage Publications.

40. Mousa, S. K., \& Othman, M. (2020). The impact of green human resource management practices on sustainable performance in healthcare organizations: a conceptual framework. Journal Cleaner Production, 243, 118595.

41. Ningsih, S., \& Segoro, W. (2014). The Influence of Customer Satisfaction. Switching Cost and Trusts in a Brand on Customer Loyalty-The Survey on Student as im3 Users in Depok. Indonesia. Procedia-Social and Behavioral Sciences, 143, 1015-1019.

42. Osei-Frimpong, K. (2019). Understanding consumer motivations in online social brand engagement participation: Implications for retailers. International Journal of Retail \& Distribution Management, 47(5), 511-529.

43. Pansari, A., \& Kumar, V. (2017). Customer engagement: The construct, antecedents, and consequences. Journal of the Academy of Marketing Science, 45(3), 294-311.

44. Ringle, C. H., Sarstedt, M., Mitchell, R., \& Gudergan, S. P. (2020). Partial least squares structural equation modeling in HRM research. The International Journal of Human Resource Management, 31(12), 1617-1643.

45. Sarstedt M., Ringle C. M., \& Hair J. F. (2017). Partial Least Squares Structural Equation Modeling. In C. Homburg, M. Klarmann \& A. Vomberg (Eds.), Handbook of Market Research (pp. 1-40). Cham: Springer.

46. Schrader, J. (2014). Flying over Social Media Strategies: Exploring the current state of the field and analyzing the social media strategies of two German airlines. University of Twente. http://essay.utwente.nl/65835. 
47. Seo, E. J., \& Park, J. W. (2018). A study on the effects of social media marketing activities on brand equity and customer response in the airline industry. Journal of Air Transport Management, 66, 36-41.

48. Shepherd, C., \& Ahmed, P. K. (2000). From product innovation to solutions innovation: a new paradigm for competitive advantage. European Journal of Innovation Management, 3(2), 100-106.

49. Sirdeshmukh, D., Singh, J., \& Sabol, B. (2002). Consumer trust, value, and loyalty in relational exchanges. Journal of Marketing, 66(1), 15-37.

50. Stone, M., Woodcock, N., Ekinci, Y., Aravopoulou, E., \& Parnell, B. (2019). SCHEMA information on marketing and customer engagement performance - reality versus dreams. The Bottom Line, 32(1), 98-116.

51. Taber, K. S. (2018). The Use of Cronbach's Alpha When Developing and Reporting Research Instruments in Science Education. Research in Science Education, 48, 1273-1296.

52. Tejada, J. J., \& Punzalan, J. R. B. (2012). On the misuse of Slovin's formula. The Philippine Statistician, 61(1), 129-136.

53. Tenenhaus, M., Amatos, S., \& Esposito Vinzi, V. (2004). A global goodness of fit index for PLS Structural equation modeling. In Proceeding of the XLII SIS Scientific Meeting (pp. 739-742).

54. Tih, S., Wong, K. K., Lynn, G. S., \& Reilly, R. R. (2016). Prototyping, customer involvement, and speed of information dissemination in new product success. Journal of Business \& Industrial Marketing, 37(4), 437-448.

55. Towner, T. L., \& Dulio, D. A. (2011). An experiment of campaign effects during the YouTube election. New Media \& Society, 13(4), 626-644.

56. Vafaei, S., Bazrkar, A., \& Hajimohammadi, M. (2019). The investigation of the relationship between sustainable supply chain management and sustainable competitive advantage according to the mediating role of innovation and sustainable process management. Brazilian Journal of Operations \& Production Management, 16(4), 572-580.

57. Vargo, S. L., \& Lusch, R. F. (2016). Institutions and axioms: An extension and update of service-dominant logic. Journal of the Academy of Marketing Science, 44(1), 5-23.

58. Wang, Z., \& Kim, H. G. (2017). Can social media marketing improve customer relationship capabilities and firm performance? Dynamic capability perspective. Journal of Interactive Marketing, 39, 15-26.

59. Weinberg, T. (2009). The new community rules: Marketing on the social web. Sebastopol, CA: O'Reilly Media.

60. Wen, W. S. (2010). Linking Bayesian networks and PLS path modeling for causal analysis. Expert Systems with Applications, 37(1), 134-139.

61. Werts, C. E., Linn, R. L., \& Joreskog, K. G. (1974). Intra class reliability estimate: testing structural assumptions. Educational \& Psychological Measurement, 34(1), 25-33.

62. Wetzels, M., Odekeken-Schroder, G., \& Van Oppen, C. (2009). Using PLS path modeling for accessing hierarchical construct models: Guidelines and empirical illustrations. MIS quarterly, 33(1), 177-195.

63. Whelan, G., Moon, J., \& Grant, B. (2013). Corporations and Citizenship Arenas in the Age of Social Media. Journal Business Ethics, 118, 777-790.

64. Yadav, M. S., Valck, K., Hennig-Thurau, T., Hoffman, D., \& Spann, M. (2013). Social commerce: a contingency framework for assessing marketing potential. Journal of Interactive Marketing, 27(4), 311-323.

65. Yim, C. K., Chan, K. W., \& Lam, S. S. K. (2012). Do customers and employees enjoy service participation? Synergistic effects of self- and other-efficacy. Journal of Marketing, 76(6), 121-140.

66. Yu, J., Zo, H., Kee Choi, M., Ciganek, A. P. (2013). User acceptance of location-based social networking services: an extended perspective of perceived value. Online Information Review, 37(5), 711-730. 